\title{
Surveys for terrestrial gastropods in the Kootenay region of British Columbia, with new records and range extensions
}

\author{
Kristina OVASKa ${ }^{1, *}$, LeNNARt SOPUCK ${ }^{1}$, and JeNNifER Heron ${ }^{2}$ \\ ${ }^{1}$ Biolinx Environmental Research Ltd., 1759 Colburne Place, North Saanich, British Columbia V8L 5A2 Canada \\ ${ }^{2}$ Ministry of Environment and Climate Change Strategy, Conservation Science Section, Suite 200, 10428153 rd Street, \\ Surrey, British Columbia V3R 1E1 Canada \\ *Corresponding author: ke.ovaska@gmail.com
}

Ovaska, K., L. Sopuck, and J. Heron. 2019. Surveys for terrestrial gastropods in the Kootenay region of British Columbia, with new records and range extensions. Canadian Field-Naturalist 133(3): 221-234. https://doi.org/10.22621/cfn. v133i3.2287

\begin{abstract}
The northern Columbia River basin, extending from the Kootenay region in British Columbia southward to the Idaho panhandle and northwestern Montana, contains a unique terrestrial gastropod fauna, but in Canada few surveys have specifically targetted this group. Here we report on terrestrial gastropods detected during surveys of 314 sites distributed in five biogeoclimatic zones across the Kootenay region. The surveys occurred on 65 days over seven years from 2007 to 2015 , usually in September-October. We detected 45 taxa identified to species, belonging to 33 genera; micro-snails of the genus Vertigo (apart from Vertigo ovata) were combined into a single category, and snails belonging to Succineidae were not identified further. Regionally endemic species previously reported from the region included Western Banded Tigersnail (Anguispira kochi occidentalis), Coeur d'Alene Oregonian (Cryptomastix mullani), Rocky Mountainsnail (Oreohelix strigosa), Subalpine Mountainsnail (Oreohelix subrudis), and Pale Jumping-slug (Hemphillia camelus), which was widespread across the region. Magnum Mantleslug (Magnipelta mycophaga), the distribution of which extends beyond the Kootenay region, was detected at several widely spaced sites. Two species new to Canada were detected, Pygmy Slug (Kootenaia burkei) and Sheathed Slug (Zacoleus idahoensis), both of which were subsequently assessed to be of conservation concern both provincially and nationally. Other notable observations included the detection of Fir Pinwheel (Radiodiscus abietum), a regional endemic, which has been previously reported only once, and three species common in coastal forests but not previously reported from the region: Pacific Banana Slug (Ariolimax columbianus), Robust Lancetooth (Haplotrema vancouverense), and Northwest Hesperian (Vespericola columbianus). Further surveys, especially at higher elevations, may reveal other additional or unusual species.
\end{abstract}

Key words: Terrestrial gastropods; new distribution records; Kootenays; inventory

\section{Introduction}

Mesic forests of the northern Columbia River basin support many unique plants and animals and species with vicarious distributions, separated from their Pacific coastal counterparts by $300 \mathrm{~km}$ or more of arid landscapes (Brunsfeld et al. 2001). This unique area extends from southeastern British Columbia (BC) and northeastern Washington southward through the Idaho Panhandle into northwestern Montana. In BC, it encompasses the Kootenay region, which supports a diverse gastropod fauna, including species that are found nowhere else in Canada (Forsyth 1999, 2004). Few studies have specifically targetted this group, and until recently our knowledge of it was based on brief historical accounts, records in Pilsbry's (1939, 1940, 1946, 1948) monograph, and largely serendipitous observations (reviewed by Forsyth 1999). Recent targetted surveys include the Royal British Columbia Museum's Living Landscape expedition (Forsyth 1999) and surveys by Nekola et al. (2011) in the central Selkirk Mountains and their vicinity in support of a proposed Selkirk Mountains Caribou Park. Increased survey efforts in this biologically rich area continue to provide new records and document species new to the province.

Here we report on surveys targetting terrestrial gastropods in southeastern BC during seven annual surveys from 2007 to 2015 (no surveys were conducted in 2011-2013), including documentation of two species of slugs new to Canada. The surveys were in support of conservation assessments by the province of $\mathrm{BC}$ and by the Committee on the Status of Endangered Wildlife in Canada (COSEWIC) and focussed on species deemed to be rare or at risk. 
Focal species initially included the snails Western Banded Tigersnail (Anguispira kochi occidentalis), Coeur d'Alene Oregonian (Cryptomastix mullani), and mountainsnail (Oreohelix) species, and the slugs Magnum Mantleslug (Magnipelta mycophaga) and Pale Jumping-slug (Hemphillia camelus). Two species, Pygmy Slug (Kootenaia burkei) and Sheathed Slug (Zacoleus idahoensis), were added after their discovery as part of this study in 2007 and 2009, respectively. The primary objective was to clarify distributions of the focal species. A secondary objective was to investigate the presence of possible undocumented species of the northern Columbia basin fauna, the distributions of which may extend northward across the international border into Canada.

\section{Study Area}

This study was conducted in the Kootenay region of southeastern BC, bounded by the Rocky Mountains to the east, the Canada-United States (USA) border to the south, Shuswap/Okanagan Highlands to the west, and the $51.6^{\circ}$ latitude to the north (Figure 1). The area consists of a series of rugged northwestsoutheast oriented mountain ranges (Rocky, Purcell, Selkirk, and Monashee), separated by large valleys, rivers, and lakes. The varied terrain and climate, which can change across short distances, result in a diversity of ecosystems, which have strong influences on terrestrial gastropod distributions.

The study area overlaps five of 14 biogeoclimatic zones in BC (BECP n.d.). A zone is classified according to the unique assemblage and distribution of climax and late-seral plant communities, energy flow, nutrient-cycling and soils, topography, and regional climate of a geographic area. Biogeoclimatic zones of the study area include high elevation Interior Mountain-heather Alpine (IMA) and Engelmann Spruce (Picea engelmannii Engelmann)-Subalpine Fir (Abies lasiocarpa (Hooker) Nuttall) (ESSF) zones; mid-elevation Interior Cedar-Hemlock (ICH) and

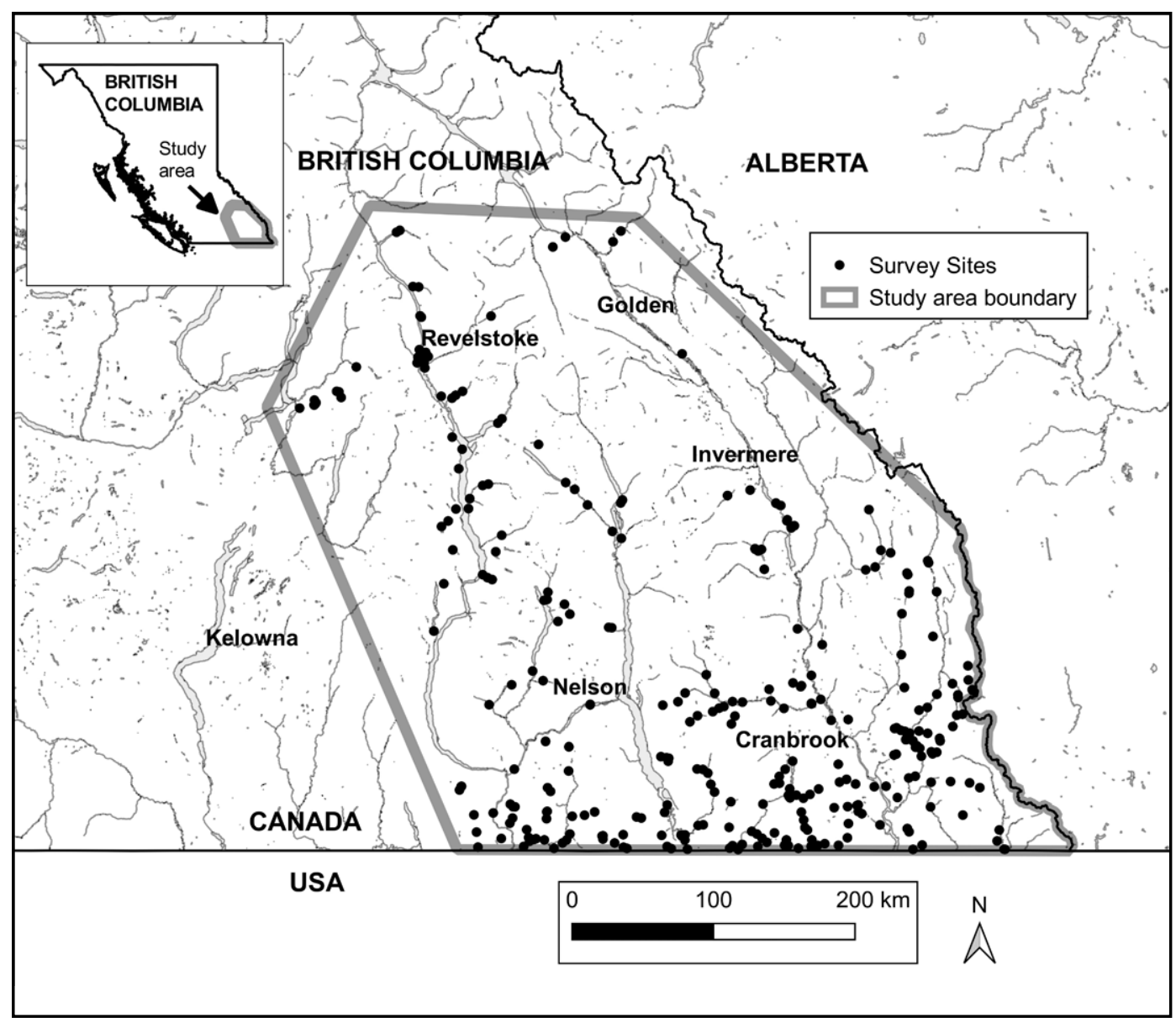

FIGURE 1. Location of the study area and sites surveyed in 2007-2015 in southeastern British Columbia. 
Montane Spruce (MS) zones; low-elevation Interior Douglas Fir (Pseudotsuga menziesii (Mirbel) Franco) (IDF) zone; and Ponderosa Pine (Pinus ponderosa Douglas ex Lawson \& C. Lawson) zone (MacKillop et al. 2018; BECP n.d.). Of the forested zones, the ESSF and ICH zones tend to have wet climates, whereas the MS and IDF zones tend to be dry. Moist Engelmann Spruce-Subalpine Fir forests dominate the higher elevations; White Spruce (Picea glauca (Moench) Voss), Western Hemlock (Tsuga heterophylla (Rafinesque) Sargent), and Western Redcedar (Thuja plicata Donn ex D. Don) forests dominate the wetter low- to mid-elevations; Lodge-pole Pine (Pinus contorta Douglas ex Loudon), Western Larch (Larix occidentalis Nuttall), and Douglas Fir forests occur on the drier mountain slopes; Ponderosa Pine and grasslands occur in the dry, low-elevation valley bottoms.

In recent years, logging, wildfires, hydroelectric reservoirs, and Mountain Pine Beetle (Dendroctonus ponderosae) epidemics have disturbed large areas of forest in the study area. The effects of cattle ranching are localized, occurring mainly in grassland and open forest habitats at low elevations. Human developments are relatively sparse, with settlements and farming occurring mainly in low-elevation river valleys, such as along the Columbia and Kootenay rivers. Several federal and provincial parks contain large areas of relatively undisturbed forest, but these are mostly restricted to higher elevations.

\section{Methods}

\section{Survey sites and effort}

We surveyed 314 sites, which were at least $500 \mathrm{~m}$ apart and distributed across the study area (Figure 1, Appendix S1); geopositions were recorded with a handheld global positioning system unit (GPSMAP $60 \mathrm{Cx}$; Garmin, Olathe, Kansas, USA). Survey efforts focussed on BC Crown forestry lands, which were accessed through logging roads that crisscrossed the area. The sites also included provincial parks $(n=5)$, national parks $(n=4)$, Ktunaxa First Nation reserve lands $(n=17)$, municipal lands $(n=6)$, and private lands used for forestry, ranching, or recreation $(n=$ 22). Most sites were searched only once, but repeated surveys were conducted at eight sites. The total time spent intensively searching for gastropods was 347 person-hours, with the median survey time one hour per site during 65 days over a seven-year period.

Survey dates, conditions, and methods

The surveys took place on the following dates: 10 16 July and 22-27 September 2007; 3-8 September and 4-7 October 2008; 6-9 October 2009; 20 July and 6-16 September 2010; 20-25 September 2013: 15-29 September 2014; and 20-25 September 2015. It rained during $16.5 \%$ of the surveys, and the median ambient temperature (measured at ground level at the start of the survey) was $11^{\circ} \mathrm{C}$ in September-October and $24^{\circ} \mathrm{C}$ in July.

To locate gastropods, usually two observers (K.O. and L.S.) walked along meandering transects through habitat deemed suitable for gastropods and examined decaying logs, piles of bark, stumps, rocks, other moist refuges, and accumulations of leaf litter, focussing on points where concentrations of such features were present. Most surveys took place during daylight hours, but a few $(n=5)$ took place on wet nights after dark to detect gastropods active on the surface. At night, we used high-watt flashlights to scan the ground surface and tree trunks while walking along trails or traversing suitable habitat and/or driving slowly along side-roads using fog lights to illuminate the road surface.

\section{Identification and vouchers}

We identified all gastropods found, in some cases only to genus (such as micro-snails of Vertigo), based on external characteristics. Identification was usually done in the field, but we collected samples of small snails and confirmed identification in the laboratory of the Royal British Columbia Museum (RBCM) using a dissecting microscope. Three specimens of Hemphillia were sent to Lyle Chichester to confirm identity through examination of distal reproductive anatomy; several species of Hemphillia occur south of the border in the USA and have not been reported from Canada. Identification was based on descriptions in Pilsbry (1940, 1948), Forsyth (2004), and Burke (2013). Nomenclature for species followed Forsyth (2004) and, for families, Bouchet et al. (2017). Voucher specimens were deposited in collections at the RBCM (Appendix S2); photographic vouchers were retained in personal collections by the authors.

\section{Results}

The surveys resulted in the detection of 45 taxa identified to species, belonging to 33 genera (Table 1). Micro-snails of the genus Vertigo (apart from Ovate Vertigo, Vertigo ovata) were combined into a single category, which included nominal taxa of Vertigo columbiana, Vertigo cristata, Vertigo gouldii, Vertigo modesta, and possibly other taxa (vouchers at RBCM). Collections of Vertigo from British Columbia await re-examination in light of the recent revision of the genus (Nekola et al. 2018). Snails of the family Succineidae were not identified below this level because of complications associated with identification based on shell morphology.

The most commonly encountered taxa were Brown Hive (Euconulus fulvus, $57 \%$ of sites surveyed), Forest Disc (Discus whitneyi, 45\%), Vertigo species group 


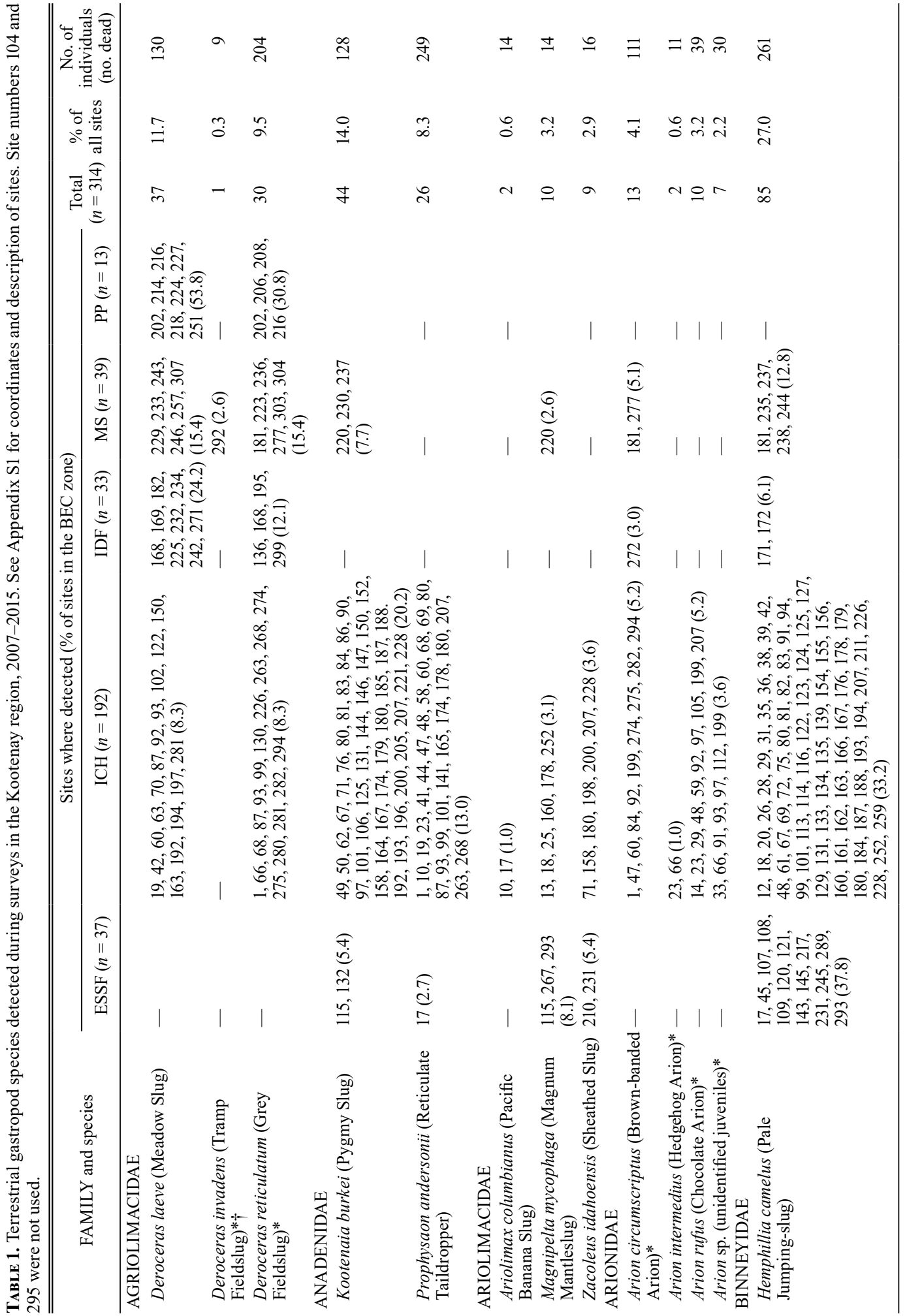




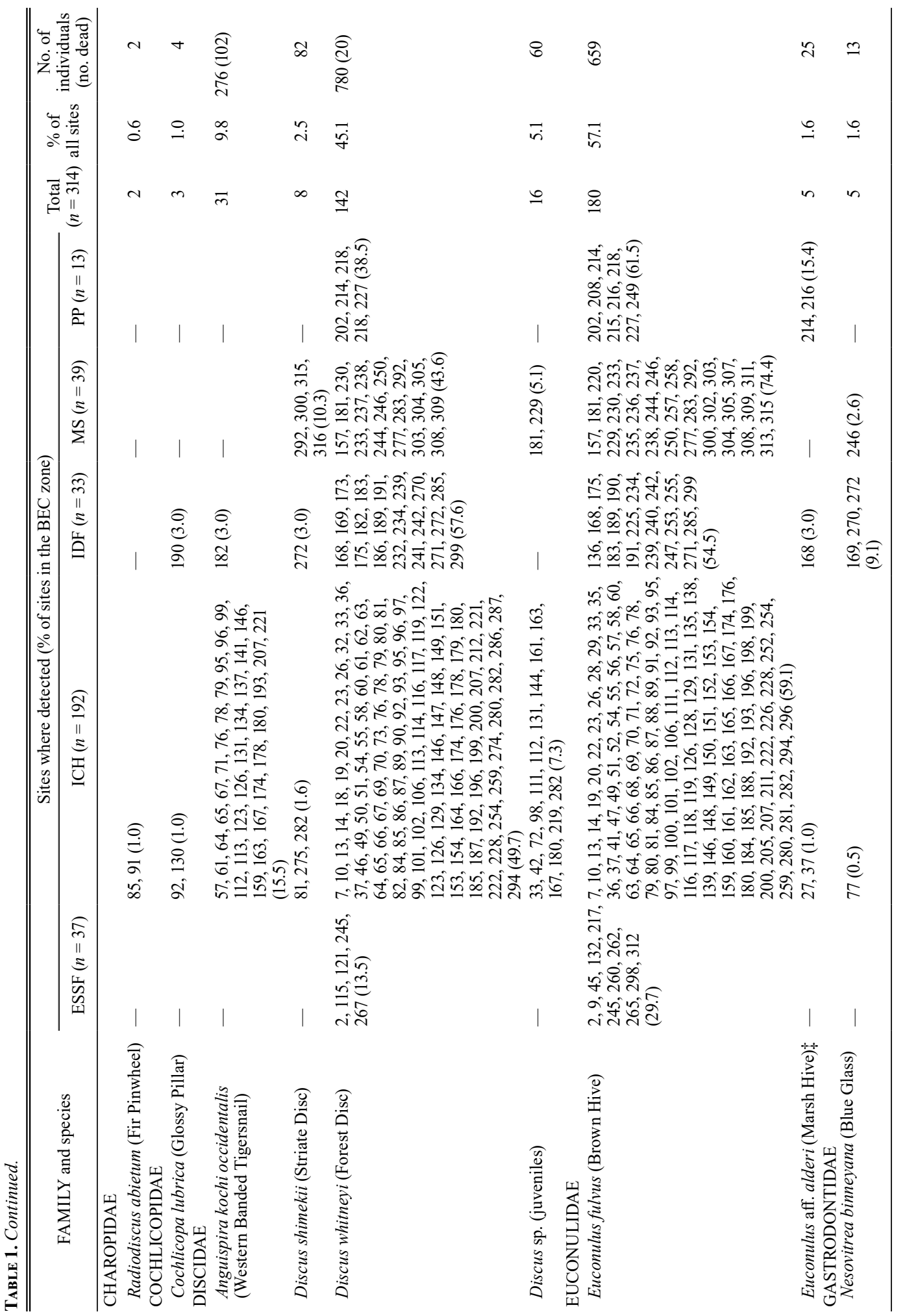




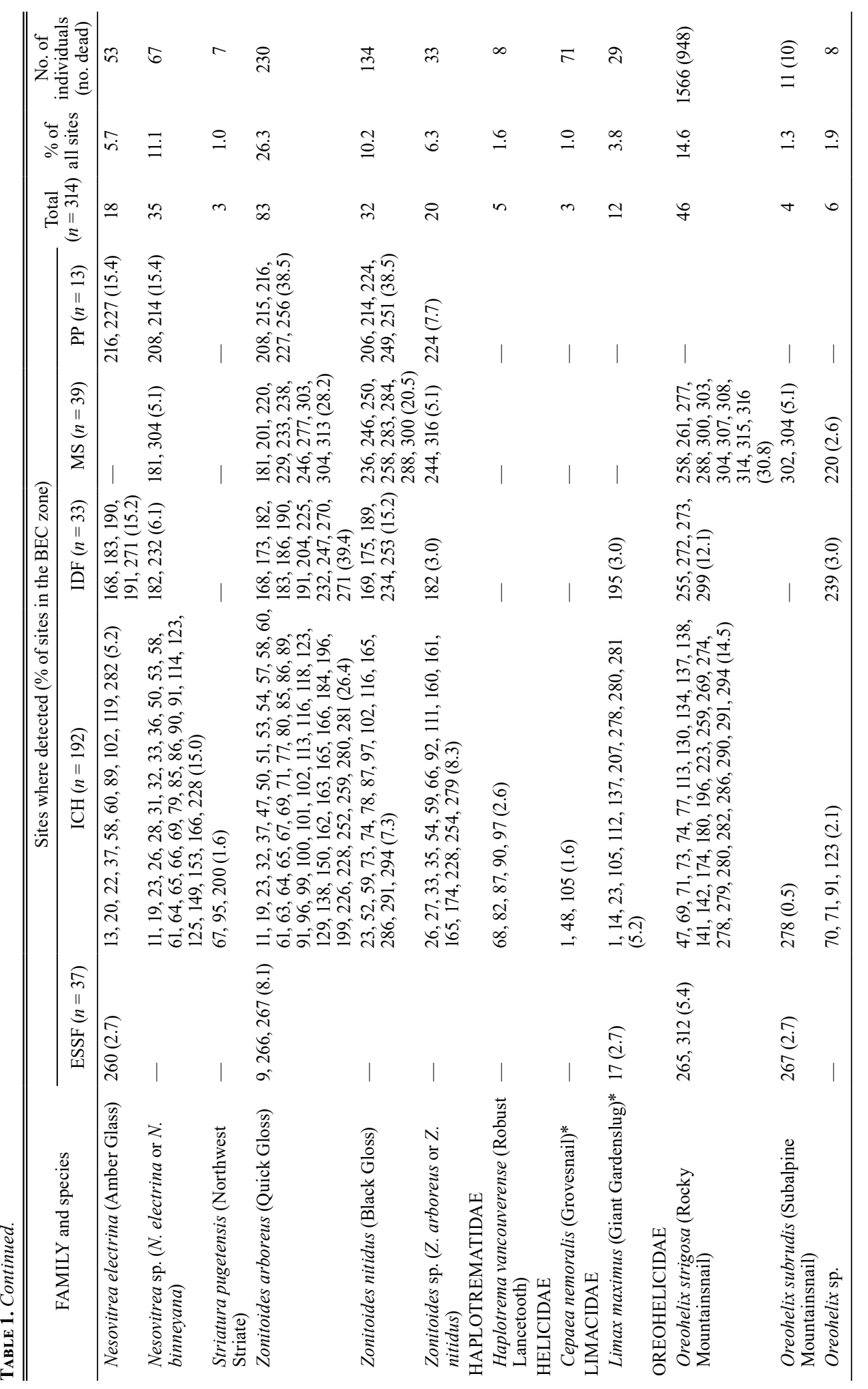




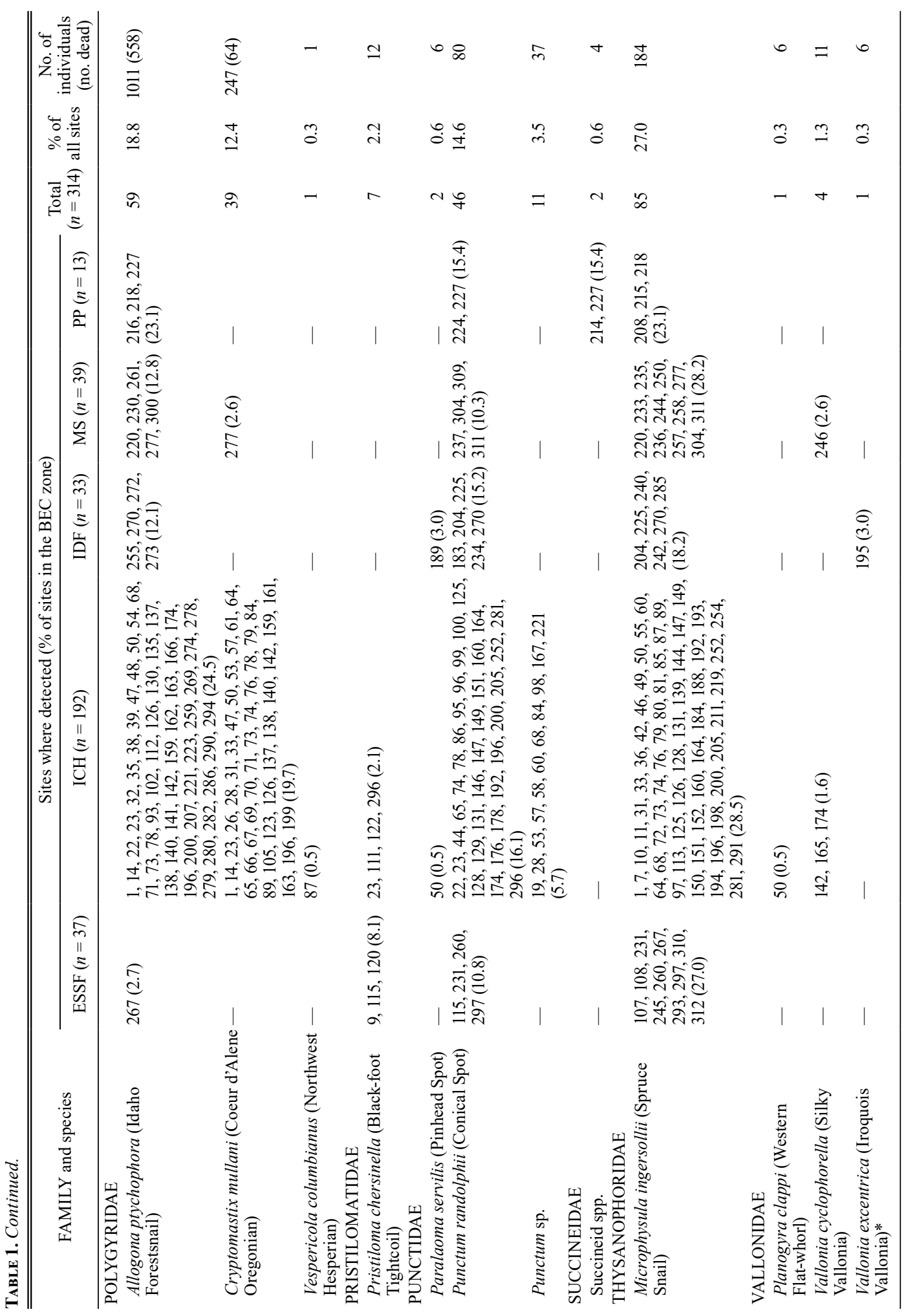




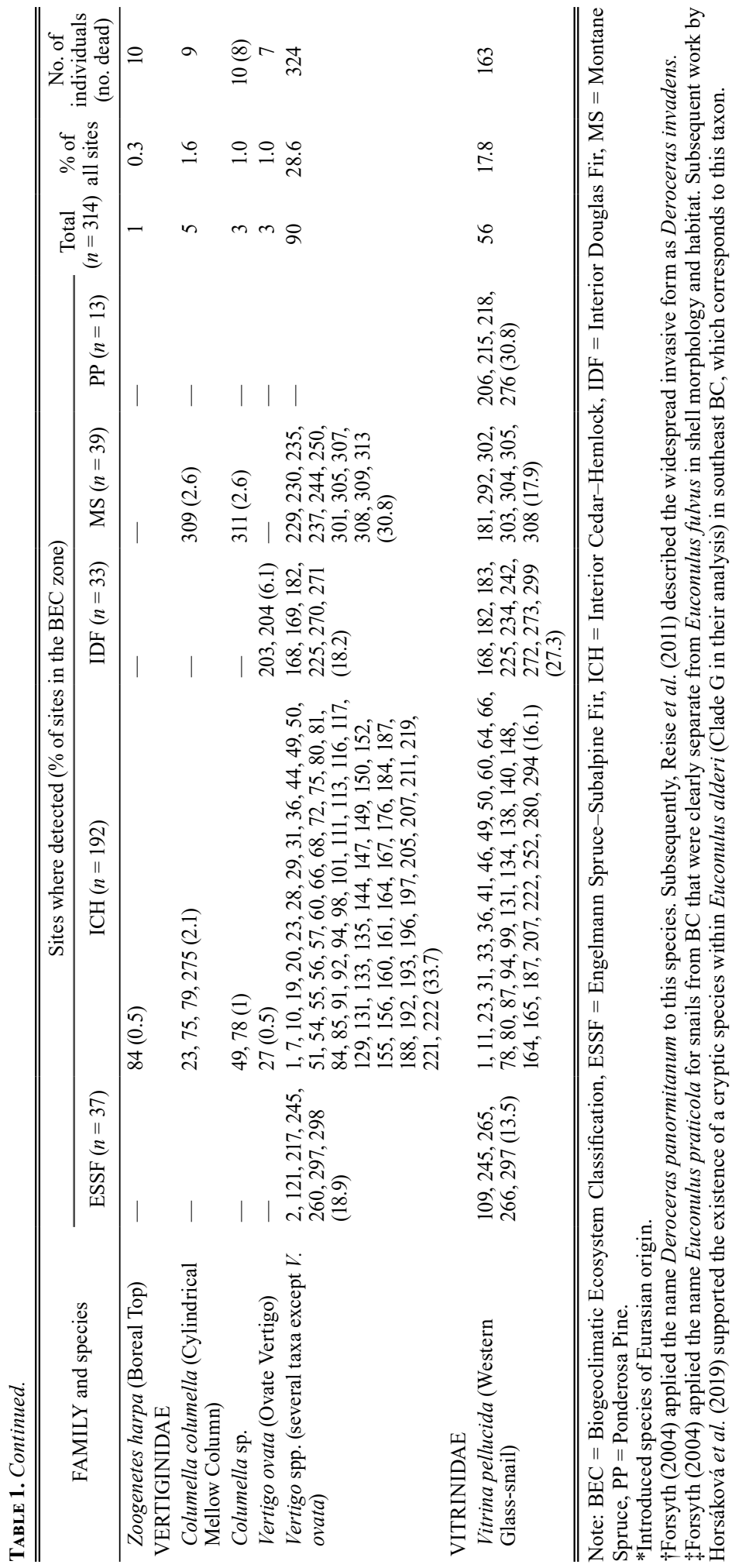


(29\%), H. camelus (27\%), Spruce Snail (Microphysula ingersollii, 27\%), Idaho Forestsnail (Allogona ptychophora, 19\%), and Western Glass-snail (Vitrina pellucida, 18\%). Four species, A. kochi occidentalis, C. mullani, K. burkei, and Reticulate Taildropper (Prophysaon andersonii), were found predominantly in the ICH zone, while others showed no obvious affinities with specific biogeographic zones. Species common in coastal forests and with vicarious or potentially vicarious coastal-inland distributions included Pacific Banana Slug (Ariolimax columbianus), Robust Lancetooth (Haplotrema vancouverense), Western Flatwhorl (Planogyra clappi), Conical Spot (Punctum randolphii), Northwest Striate (Striatura pugetensis), and Northwest Hesperian (Vespericola columbianus); all were encountered at only a small number of sites (Table 1).

Of the focal species, M. mycophaga was detected infrequently at widely spaced sites, all except one of which (Mount Revelstoke) represented new localities for the species (Figure 2); the previous record from Mount Revelstoke, a specimen collected in 1937 by K. Racey, was discovered in February 2014 by one of us (K.O.) during examination of unidentified gastropod specimens catalogued in the RBCM collection. Hemphillia camelus was widespread within the study area and the most commonly encountered slug. We detected no obvious morphological differences among individuals or sites that would suggest the presence of more than one species; reproductive anatomy of a small number of dissected specimens $(n=3)$ conformed with this species. Anguispira kochi occidentalis, C. mullani, and K. burkei were detected mainly in the western portion of the study area. Records for $Z$. idahoensis were confined to a relatively small area in the south within $\sim 25 \mathrm{~km}$ of the Canada-USA border (Figure 2), while the other species were more widespread. In contrast, Oreohelix species were found mainly toward the Rocky Mountains in the eastern portion of the study area, where they appeared to be exceedingly abundant at many sites. We identified most of the specimens as Rocky Mountainsnail (Oreohelix strigosa) based on shell morphology, but there was much variability in shell shape and size both within and among sites. Snails in subalpine habitats with a relatively high spire were identified as Subalpine Mountainsnail (Oreohelix subrudis). As noted by Forsyth (2004), taxa referred to as $O$. strigosa and C. mullani in BC may in fact each consist of species complexes that may include as yet unidentified species, as also appears to be the case on the USA side of the border to the south (Burke 2013). Selected species detected during the surveys are featured in Figure 3.

\section{Discussion}

Terrestrial gastropods detected during the surveys represent several faunal elements including widespread species, some with holarctic distributions, regional endemics to the Columbia basin and surrounding mountains, those with vicarious distributions with a coastal and interior component, and introduced species of Eurasian origin. Examples of widespread native species include Meadow Slug (Deroceras laeve), D. whitneyi, E. fulvus, M. ingersollii, and Quick Gloss (Zonitoides arboreus). Regionally endemic species previously reported from the region include $A$. kochi occidentalis, C. mullani, $H$. camelus, $O$. strigosa, and $O$. subrudis.

In addition to providing numerous new records for the regionally endemic focal species, the surveys resulted in the documentation of two species of slugs new to Canada, $K$. burkei and Z. idahoensis. Both species were subsequently determined to be of conservation concern in Canada (COSEWIC 2016a,b). Kootenaia burkei was described only recently from specimens from Idaho (Leonard et al. 2003), and before this study it was known from the Idaho Panhandle and northwestern Montana. The known distribution of Z. idahoensis was similar (Burke 2013). This study revealed that a large proportion $(\sim 35 \%)$ of the global distribution of $K$. burkei is in Canada, whereas the Canadian distribution of $Z$. idahoensis appears to be much more restricted.

Other interesting observations include the detection of Fir Pinwheel (Radiodiscus abietum), a regional endemic, at two sites in September 2013 (Figure 4). To our knowledge, this species has been documented from Canada previously only by Nekola et al. (2011), who found it at five localities in New Denver, BC, and in the lowlands southward in 2011. We detected Boreal Top (Zoogenetes harpa), a species with a holarctic distribution, at only one site. This species is known to occur sporadically in northern BC and along the Rocky Mountains (Forsyth 2004), but appears to be rare and/or patchily distributed in the Kootenay region.

Of the species common in Pacific coastal forests and with apparently vicarious distributions, $P$. clappi and $S$. pugetensis were detected infrequently and appear to be very patchily distributed in the study area. Both species have been reported previously from a small number of sites in the Kootenay region (Nekola et al. 2011). Additional species with such distributions detected for the first time during the surveys were $A$. columbianus at two sites, both of which receive heavy recreational use, $H$. vancouverense at five sites, and $V$. columbianus at one site, a moist, disturbed site along the highway near the international border where the latter two species co-occurred. Whether the presence 

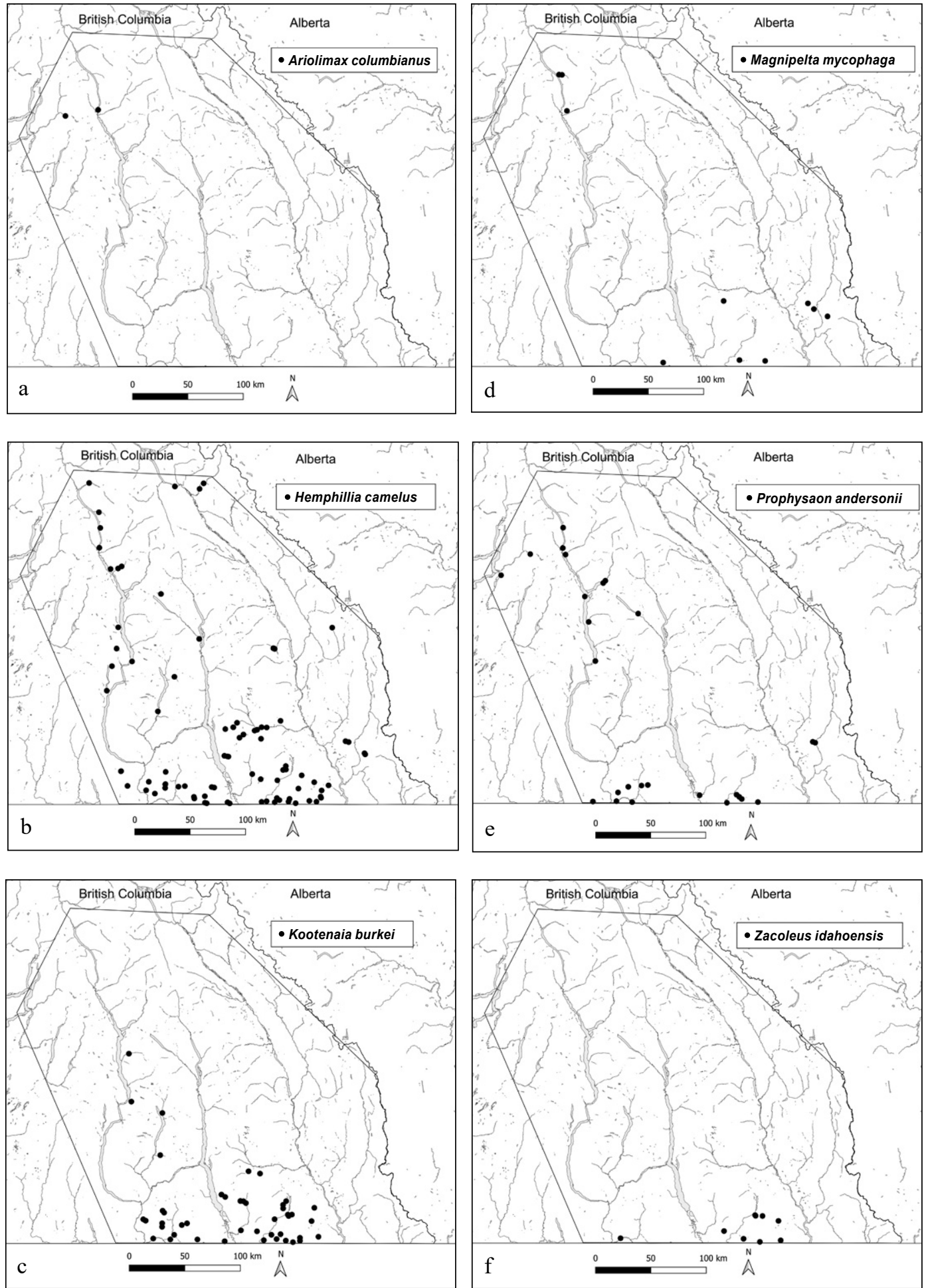

Figure 2. Comparison of the distributions of selected species of slugs, a-f, and large snails, g-1, detected in the study area in southeastern British Columbia. 

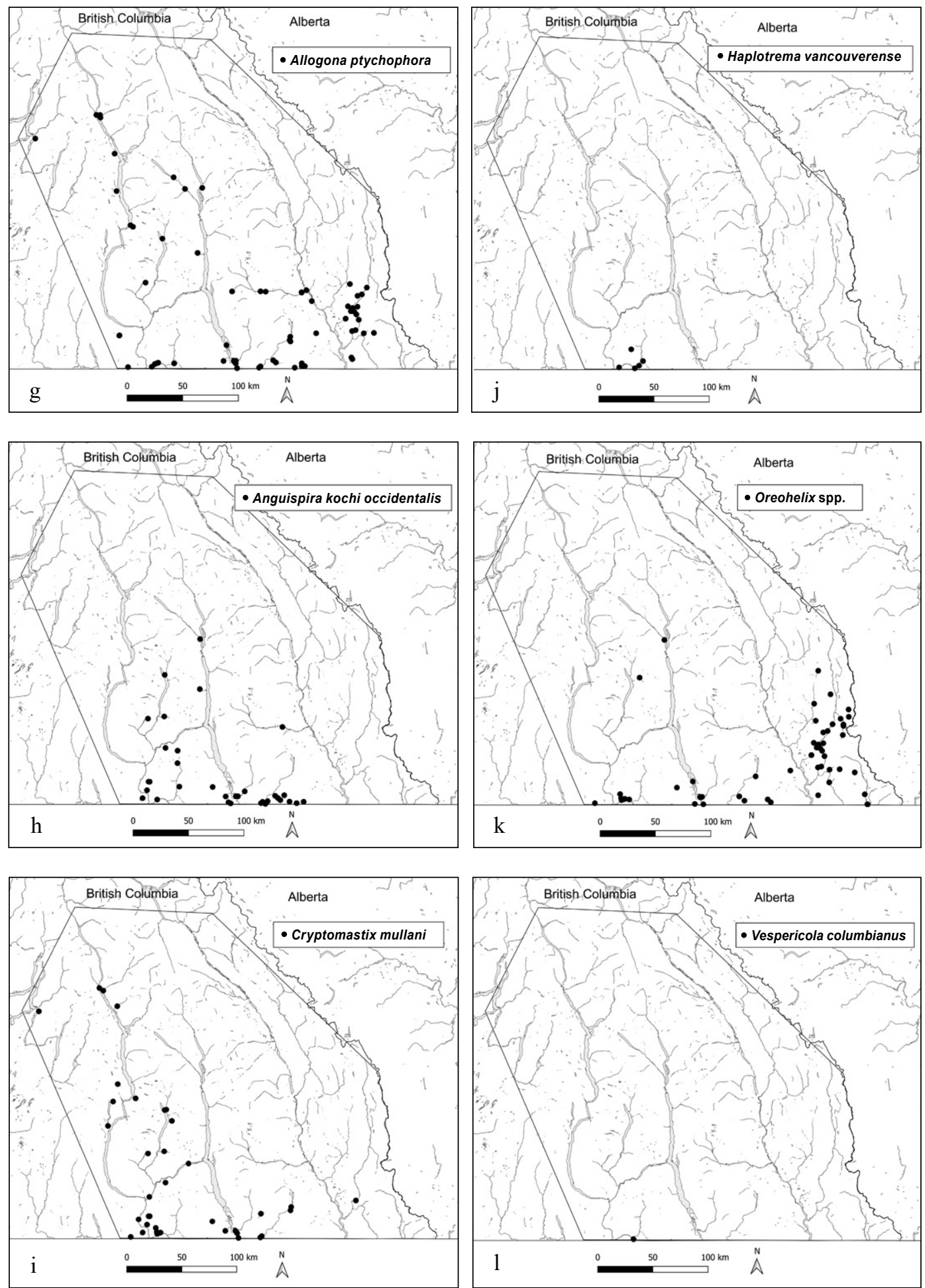

Figure 2. Continued. 

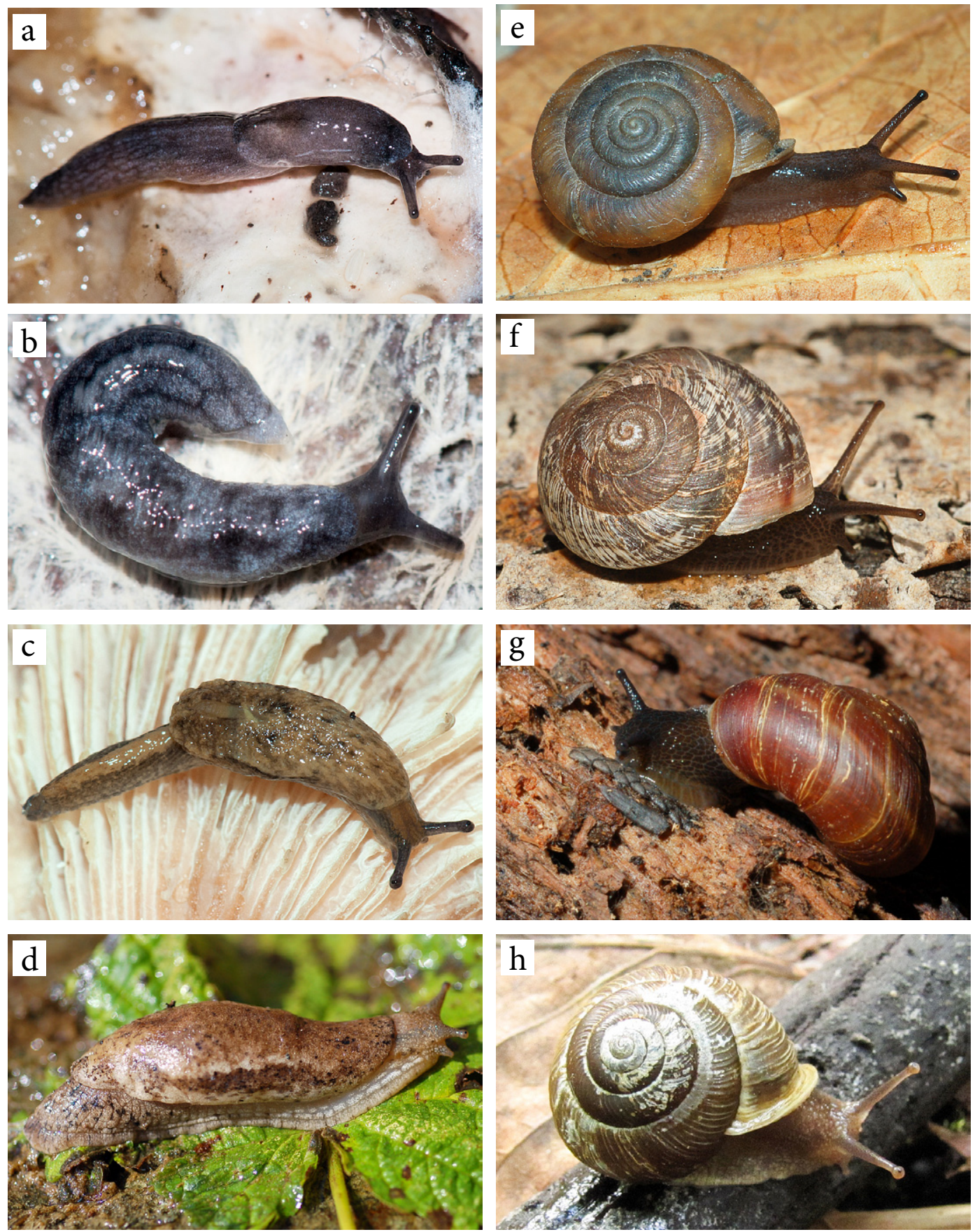

Figure 3. Selected species detected during surveys in the Kootenay region, 2007-2015. a. Sheathed Slug, Zacoleus idahoensis (September 2013, site 158, 25 mm, in situ); b. Pygmy Slug, Kootenaia burkei (September 2014, site 230, $12 \mathrm{~mm}$, in situ); c. Pale Jumping-slug, Hemphillia camelus (September 2014, site 83, juvenile $35 \mathrm{~mm}$, in situ); d. Magnum Mantleslug, Magnipelta mycophaga (July 2007, site 267, 65 mm, in situ); e. Coeur d'Alene Oregonian, Cryptomastix mullani (September 2007, site 142, 15 mm); f. Rocky Mountainsnail, Oreohelix strigosa (September 2007, site 142, 20 mm); g. Western Banded Tigersnail, Anguispira kochi occidentalis (3 September 2008, site 78, $25 \mathrm{~mm}$, in situ); h. Idaho Forestsnail, Allogona ptychophora (September 2010, site 14, $22 \mathrm{~mm}$ ). Size is extended length for slugs, shell width for snails. Photos: Kristiina Ovaska. 

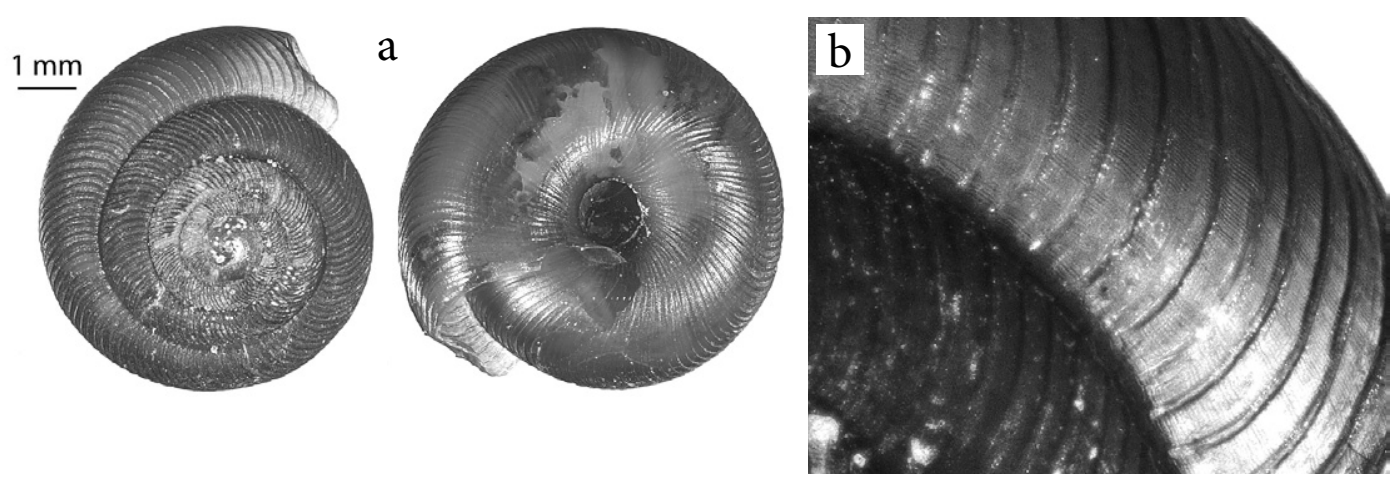

Figure 4. a. Fir Pinwheel, Radiodiscus abietum (23 September 2013, site 85) from the Kootenay region. b. Detail of shell with diagnostic fine spiral striae. Photos: Kristiina Ovaska and Heidi Gartner.

of these species represents natural distribution or resulted from recent introductions by humans from the coast remains unknown.

Non-native species encountered during the surveys include the snails Iroquois Vallonia (Vallonia excentrica) at one site, adjacent to hot springs at a recreational site, and Grovesnail (Cepaea nemoralis) at three lower elevation sites, two of them in provincial parks. Introduced slugs of three families (Agriolimacidae, Arionidae, Limacidae) were widespread within the study area and occurred at 51 sites (16.2\%), distributed across all five biogeoclimatic zones sampled and often associated with human-modified habitats.

This study contributes to a growing body of information on distributions of terrestrial gastropods of southeastern BC. Most of the sampling sites were in the ICH biogeoclimatic zone, which was expected to provide suitable habitat for most of the focal species. Higher elevation sites in the ESSR and MS zones, in particular, merit further surveys, but pose logistic challenges because of difficulties of access. Yet, these habitats may contain unique species and faunas that might be particularly vulnerable to climate change impacts, as reported in other areas (Müller et al. 2009).

\section{Author Contributions}

Writing - Original draft: K.O. and L.S.; Writing - Review \& editing: K.O., L.S., and J.H.; Conceptualization: K.O., L.S., and J.H.; Surveys \& specimen identification: K.O. and L.S.; Logistics \& landowner contacts: J.H.; Funding acquisition: J.H.

\section{Acknowledgements}

We are grateful to all individuals and organizations who partnered with us and helped make this project possible, including landholders and managers who allowed us on their lands. We particularly acknowledge Ktunaxa First Nations representatives on Aqam and Akisqnuk Reserves, Ted Antifeau, Lindsay Anderson, Kari Stewart-Smith, Ian Adams, Darren Komonoski,
Zehnder Farms, Wayne Stetski, and Nancy Newhouse, for their assistance in selecting and accessing survey sites. Laura Parkinson, Kyle Shottanana, and Christian Engelstoft provided able field assistance during parts of the study. Lyle Chichester performed dissections of Hemphillia specimens. Heidi Gartner diligently and expediently catalogued voucher specimens at Royal British Columbia Museum. Robert Forsyth and Dwayne Lepitzki provided helpful comments, which greatly improved the manuscript. Funding was provided by the BC Ministry of Environment and Climate Change Strategy and BC Ministry of Forests, Lands, Natural Resource Operations and Rural Development. Additional funding came from Environment Canada through the Habitat Stewardship Program for surveys in 2010 and through the Committee on the Status of Endangered Wildlife in Canada for field verification associated with the preparation of status reports in 2013 and 2014. The Royal British Columbia Museum and BC Parks Enhancement Fund contributed to travel expenses associated with the surveys.

\section{Literature Cited}

BECP (Biogeoclimatic Ecosystem Classification Program). n.d. Zone and provincial classification reports. Research Branch, Ministry of Forestry, Victoria, British Columbia, Canada. Accessed April 2019. https://www. for.gov.bc.ca/HRE/becweb/resources/classification reports/provincial/index.html.

Bouchet, P., J.-P. Rocroi, B. Hausdorf, A. Kaim, Y. Kano, A. Nützel, P. Parkhaev, M. Schrödl, and E.E. Strong. 2017. Revised classification, nomenclator and typification of gastropod and monoplacophoran families. Malacologia 61: 1-526. https://doi.org/10.4002/040. 061.0201

Brunsfeld, S.J., J. Sullivan, D.E. Soltis, and P.S. Soltis. 2001. Comparative phylogeography of northwestern North America: a synthesis. Pages 319-339 in Integrating Ecology and Evolution in a Spatial Context. Edited by J. Silvertown and J. Antonovics. Blackwell Science, Oxford, United Kingdom. 
Burke, T. 2013. Snails and Slugs of the Pacific Northwest. Oregon State University Press, Corvallis, Oregon, USA.

COSEWIC (Committee on the Status of Endangered Wildlife in Canada). 2016a. COSEWIC assessment and status report on the Pygmy Slug Kootenaia burkei in Canada. COSEWIC, Ottawa, Ontario, Canada.

COSEWIC (Committee on the Status of Endangered Wildlife in Canada). 2016b. COSEWIC assessment and status report on the Sheathed Slug Zacoleus idahoensis in Canada. COSEWIC, Ottawa, Ontario, Canada.

Forsyth, R.G. 1999. Terrestrial malacology in the Columbia Basin, British Columbia. Living Landscape project, Royal British Columbia Museum, Victoria, British Columbia. Accessed March 2019. https://royalbcmuseum. bc.ca/exhibits/living-landscapes/cbasin/molluscs/intro duction 2.html.

Forsyth, R.G. 2004. Land Snails of British Columbia. Royal British Columbia Museum, Victoria, British Columbia, Canada.

Horsáková, V., J.C. Nekola, and M. Horsák. 2019. When is a "cryptic" species not a cryptic species: a consideration from the holarctic micro-landsnail genus Euconulus (Gastropoda: Stylommatophora). Molecular Phylogenetics and Evolution 132: 307-320. https://doi.org/10. 1016/j.ympev.2018.12.004

Leonard, W.P., L. Chichester, J. Baugh, and T. Wilke. 2003. Kootenaia burkei, a new genus and species of slug from northern Idaho, United States (Gastropoda: Pulmonata: Arionidae). Zootaxa 355: 1-16. https://doi. org/10.11646/zootaxa.355.1.1

MacKillop, D., A. Ehman, K. Iverson, and E. McKenzie. 2018. A Field Guide to Ecosystem Classification and Identification for Southeast British Columbia: the East Kootenay. Land Management Handbook 71. Government of British Columbia, Victoria, British Columbia, Canada. Accessed 14 January 2020. https://www.for. gov.bc.ca/hfd/pubs/docs/lmh/LMH71.pdf.
Müller, J., C. Bässler, C. Strätz, B. Klöcking, and R. Brandl. 2009. Molluscs and climate warming in a low mountain range national park. Malacologia 51: 89-109. https://doi.org/10.4002/040.051.0106

Nekola, J.C., S. Chiba, B.F. Coles, C.A. Drost, T. von Proschwitz, and M. Horsák. 2018. A phylogenetic overview of the genus Vertigo O. F. Müller, 1773 (Gastropoda: Pulmonata: Pupillidae: Vertigininae). Malacologia 61: 21-161. https://doi.org/10.4002/040.062.0104

Nekola, J., B. Coles, and M. Horsak. 2011. Land snail biodiversity assessment for the Selkirk Mountains Park region in southeastern British Columbia. Unpublished report. Valhalla Wilderness Society, New Denver, British Columbia, Canada.

Pilsbry, H.A. 1939. Land Mollusca of North America (north of Mexico). Monograph 3, 1(1): i-xvii, 1-573, i-ix. Academy of Natural Sciences of Philadelphia, Philadelphia, USA.

Pilsbry, H.A. 1940. Land Mollusca of North America (north of Mexico). Monograph 3, 1(2): 575-994, i-ix. Academy of Natural Sciences of Philadelphia, Philadelphia, USA.

Pilsbry, H.A. 1946. Land Mollusca of North America (north of Mexico). Monograph 3, 2(1): i-iv, 1-520, i-ix, frontispiece. Academy of Natural Sciences of Philadelphia, Philadelphia, USA.

Pilsbry, H.A. 1948. Land Mollusca of North America (north of Mexico). Monograph 3, 2(2): i-xlvii, 521-1113. Academy of Natural Sciences of Philadelphia, Philadelphia, USA.

Reise, H., J.M.C. Hutchinson, S. Schunack, and B. Schlitt. 2011. Deroceras panormitanum and congeners from Malta and Sicily, with a redescription of the widespread pest slug as Deroceras invadens n. sp. Folia Malacologica 19: 201-233. https://doi.org/10.2478/v101 25-011-0028-1

Received 15 May 2019

Accepted 27 December 2019

\section{SUPPLEMENTARY Material:}

Appendix S1. List of sites surveyed for terrestrial gastropods in the Kootenay region, British Columbia, $2007-2015$.

Appendix S2. List of voucher specimens deposited to collections at Royal British Columbia Museum, Victoria, British Columbia. 